School of Finance

University of St.Gallen

CASH HOLDINGS AND THE PERFORMANCE OF EUROPEAN MUTUAL FUNDS

FRANK GRAEF

PASCAL VOGT

VOLKER VONHOFF

FLORIAN WEIGERT

WORKING PAPERS ON FinANCE No. 2018/7

SWISS INSTITUTE OF BANKING AND FINANCE (S/BF - HSG)

FEBRUARY 2018 


\title{
Cash Holdings and the Performance of European Mutual Funds
}

\author{
Frank Graef, Pascal Vogt, Volker Vonhoff, and Florian Weigert* \\ This Version: February 2018
}

\begin{abstract}
We investigate the determinants and performance implications of cash holdings for a large sample of actively-managed equity funds domiciled in the European Union (EU). In line with recent evidence from the US, we observe that cash holdings are strongly influenced by a fund's fee structure, past flows and flow volatility, and a fund's investment strategy. EU Funds with cash holdings in excess of the level predicted by fund attributes (i.e., high abnormal cash funds) outperform their low abnormal cash peers by risk-adjusted $0.96 \%$ per annum.
\end{abstract}

Keywords: Cash holdings, mutual funds, performance evaluation.

JEL Classification Numbers: G10, G11, G15, G23.

*Frank Graef is from the University of St. Gallen, Switzerland; address: Unterer Graben 21, 9000 St. Gallen, Switzerland; e-mail: frank.graef@student.unisg.ch. Pascal Vogt is from the Boston Consulting Group (BCG); address: Im Mediapark 8, 50670 Cologne, Germany; telephone: ++49-170-334-5213; e-mail: vogt.pascal@bcg.com. Volker Vonhoff is from the Boston Consulting Group (BCG); address: 10 Hudson Yards, New York NY 10001, USA; telephone: ++1-212-920-7160; e-mail: vonhoff.volker@bcg.com. Florian Weigert is from the School of Finance, Swiss Institute of Banking and Finance, University of St. Gallen; address: Unterer Graben 21, 9000 St. Gallen, Switzerland; telephone: ++41-71-224-7014; e-mail: florian.weigert@unisg.ch. All errors are our own. 


\title{
Cash Holdings and the Performance of European Mutual Funds
}

\begin{abstract}
We investigate the determinants and performance implications of cash holdings for a large sample of actively-managed equity funds domiciled in the European Union (EU). In line with recent evidence from the US, we observe that cash holdings are strongly influenced by a fund's fee structure, past flows and flow volatility, and a fund's investment strategy. EU Funds with cash holdings in excess of the level predicted by fund attributes (i.e., high abnormal cash funds) outperform their low abnormal cash peers by risk-adjusted $0.96 \%$ per annum.
\end{abstract}

Keywords: Cash holdings, mutual funds, performance evaluation.

JEL Classification Numbers: G10, G11, G15, G23. 


\section{Introduction}

Cash is a crucial component of actively-managed mutual funds' portfolios. At the end of 2016, total worldwide assets invested in regulated open-end mutual funds exceeded USD 40 trillion - with more than USD 12 trillion invested in funds domiciled in the European Union (Investment Company Factbook, 2017). At the same point in time, funds domiciled in the European Union (EU funds) hold 3.31\% of their total net assets (TNA) in cash which corresponds to a total amount of more than USD 410 billion. Interestingly, cash holdings considerably differ among seemingly comparable funds. As an example, one quintile of EU equity funds with a growth objective held over $8.04 \%$ of their TNA in cash at the end of 2016, while another quintile only held $0.17 \%$. How can these differences be explained, and do these differences also translate into significant spreads in future fund performance?

Despite their practical importance, cash holdings of EU equity funds have received no direct attention in the academic literature where previous studies have exclusively focused on the US market. Chordia (1996) and Yan (2006) investigate the link between cash holdings and a number of fund characteristics. They find, among others, that cash holdings increase with uncertainty about investor redemptions and decrease with load fees (Chordia, 1996), and that cash is positively correlated with a fund's expense ratio, past flows and flow volatility (Yan, 2006). More recently, Simutin (2014) examines the relationship between abnormal cash - i.e., cash holdings in excess of the level predicted by fund attributes - and US funds' future performance. Against the notion that cash holdings impose severe opportunity costs, since they prevent investments into equity, Simutin (2014) finds that US funds with high abnormal cash holdings outperform their low abnormal cash counterparts by roughly $2 \%$ per annum. ${ }^{1}$

This paper is the first to study the determinants of cash holdings and the performance implications of abnormal cash for a large sample of 1,464 EU equity funds in the time period from 2004 to 2017. We obtain the following results: First, the level of cash holdings is strongly linked to a fund's fee structure, past flows and flow volatility, and a fund's investment strategy. In particular, funds with a high expense ratio, high past flows and flow volatility, and high sensitivities to the market and the size factor of Fama and French (1993) show high cash ratios. Interestingly, these relationships are robust for a control sample of

\footnotetext{
${ }^{1}$ Another string of literature focuses on the importance of cash for funds' liquidity management. Edelen (1999) argues that flow shocks trigger liquidity-motivated trading by fund managers, in order to avoid large fluctuations in cash positions. Hanouna, Novak, Riley, and Stahel (2015) examine the interaction between fund flows, cash holdings, and liquidity of fund portfolios for the US mutual fund industry. Chernenko and Sunderam (2016) study liquidity transformation in mutual funds. They find that mutual funds hold substantial amounts of cash which they use to accommodate inflows and outflows rather than transacting in the underlying portfolio assets.
} 
2,166 US equity mutual funds (in the identical sample period). Hence, the main drivers of cash holdings seem to be similar for both US and EU funds.

Second, in line with the results of Simutin (2014), we find that EU funds with high abnormal cash holdings significantly outperform funds with low abnormal cash holdings. This outperformance amounts to $0.96 \%$ per annum risk-adjusted for the Carhart (1997) model (i.e., risk-adjusted for the market-, size-, value-, and momentum factor). We observe that this outperformance is economically similar among the three EU countries with the highest number of funds in our sample (i.e., Luxembourg, France, and Germany). Hence, our results support the idea that abnormal cash can be seen as a proxy for managerial ability enabling the fund manager to make superior stock selection decisions and also helps to retain the fund from costly fire sales triggered by unexpected outflows.

The remainder of the paper is as follows: Section 2 introduces the data and main variables. In Section 3 we investigate determinants of funds' cash holdings. Section 4 examines the relationship between (abnormal) cash and future performance. We conclude in Section 5 .

\section{Data and Main Variables}

We obtain semi-annual data for equity funds from the US and the EU from the Morningstar database in the time period from 2001 to the first half of $2017 .{ }^{2}$ To prevent that our examination is distorted by very small funds, we restrict our sample to funds with TNA larger than USD 20 million. We exclude index funds, ETFs and closed-end funds from the analysis and require that the investment focus of a fund is 'domestic' or 'global'. 3 To avoid the inclusion of non-equity funds, we require all funds to allocate at least $80 \%$ of the TNA in equity.

To compute funds' sensitivites to different risk factors we apply the US Carhart (1997) four-factor model for US funds, and the European Carhart (1997) four-factor model for EU funds. ${ }^{4}$ Individual fund betas with regard to the market factor (MKT), the size factor (SMB), the value factor (HML), and the momentum factor (UMD) are then estimated over a rolling horizon of 36 months using monthly return data. ${ }^{5}$ Our final sample consists of 56,572 fund-half-year observations including 3,630 unique equity funds in the time period from 2004 to the first half of 2017. The sample splits up into 2,166 US funds and 1,464 EU funds. We

\footnotetext{
${ }^{2}$ The starting date of our analysis is justified by the availability of cash holdings for the majority of funds in our sample starting in 2001.

${ }^{3}$ All our results are robust if we only include funds with the investment focus "domestic" in the empirical analysis.

${ }^{4}$ Data for the monthly US and European risk factors is retrieved from Kenneth French's webpage.

${ }^{5}$ Hence, the rolling estimation horizon shortens the sample period by three years.
} 
report the exact number of funds for each individual country in Panel A of Table 1. Among the 15 EU countries in our sample, Luxembourg (469), France (410), and Germany (188) are the countries with the highest number of individual funds.

[Insert Table 1 about here]

We display summary statistics for the main variables in our study (separately for the US and the EU sample) in Panel B of Table 1. These are a fund's cash holdings (in \% of TNA), size (log of TNA), age (in years), the expense ratio (in \%), six-months return (in \%), six-months flow (scaled by TNA of the past period, in \%), flow volatility (computed as the volatility of monthly net flows over the past 36 months), and sensitivites with regard to the market return (MKT), the size factor (SMB), the value factor (HML), and the momentum factor (UMD) of the Carhart (1997) four-factor model. We also report the respective mean differences for each variable in the last column of Panel B. Among others, we observe that average cash holdings of EU funds are $3.42 \%$ of TNA and are significantly higher than average cash holdings of US funds with $3.04 \%$ of TNA.

To get some idea about the temporal variation of cash over time, we investigate the time series of aggregate cash for US and EU funds. We define aggregate cash as the semi-annual cross-sectional, equal-weighted average of cash over all funds in the sample. Figure 1 plots the time series of aggregate cash for US and EU funds.

[Insert Figure 1 about here]

Visual inspection shows that (in line with our summary statistics) aggregate cash is higher for EU funds than for US funds in most of the time periods. Moreover, we observe that both time series are slightly declining over time. The highest point in aggregate cash for US funds occurs in the beginning of our sample period in the first half of 2004, whereas aggregate EU cash peaks in the first half of 2009 (the time period after the bankruptcy of Lehman Brothers and the beginning of a global financial crisis).

\section{Determinants of Cash Holdings}

In this section we examine the determinants of funds' cash holdings. We regress fund $i$ 's cash holdings in period $t+1$ on a set of different fund characteristics, all measured in period $t$ as described in Section 2. We follow Simutin (2014) and run multivariate Fama and MacBeth (1973) regressions on the individual fund level: 


$$
\begin{aligned}
& \operatorname{Cash}_{i, t+1}=\alpha+\beta_{1} \cdot \operatorname{Size}_{i, t}+\beta_{2} \cdot \operatorname{Age}_{i, t}+\beta_{3} \cdot \operatorname{Expenses}_{i . t}+\beta_{4} \cdot \operatorname{Return}_{i, t}+\beta_{5} \cdot \text { Flow }_{i . t}+ \\
& \beta_{6} \text {. Flow } \operatorname{Vola}_{i, t}+\beta_{7} \cdot \beta_{M K T_{i . t}}+\beta_{8} \cdot \beta_{S M B_{i . t}}+\beta_{9} \cdot \beta_{H M L_{i . t}}+\beta_{10} \cdot \beta_{U M D_{i . t}}+\epsilon_{i, t+1} \text {. }
\end{aligned}
$$

T-statistics are computed using Newey and West (1987) standard errors with four lags to control for serial correlation. Table 2 reports the results of the regression analysis.

[Insert Table 2 about here]

In specifications (1) - (3) we display the results for the pooled sample, as well as for the US and the EU sample. We find that five out of the ten explanatory variables have a significant positive effect on a fund's cash sholdings in all three samples: the expense ratio, past flows and flow volatility, and risk loadings with regard to the market and the SMB factor. ${ }^{6}$ These results are intuitive and show that cash holdings are strongly affected by (i) fund expenses which have to be paid in cash, (ii) fund share purchases and redemptions by investors, and (iii) the investment strategy of the fund manager (i.e., funds with higher market and SMB risk loadings hold more cash to hedge themselves against downturns and to remain liquid). We confirm most of these significant relationships when we run the identical regression for the three countries with the highest number of funds in the EU sample (i.e., Luxembourg, France, and Germany) in specifications (4) to (6).

\section{Performance Implications of Cash and Excess Cash}

Cash is typically seen as a drag to fund performance because it prohibits the fund manager from earning the equity risk premium. However, Simutin (2014) shows that US funds with cash holdings in excess of the level predicted by fund attributes (i.e., high abnormal cash funds) exhibit higher future performance than their low abnormal cash peers. We test this conjecture out-of-sample using our EU fund dataset.

First, we examine the relationship between raw cash holdings in period $t$ and future fund performance in period $t+1$ and perform equal-weighted univariate portfolio sorts. For each month $t$, we sort all funds into quintile portfolios based on cash in increasing order. We then compute the equal-weighted average returns of these portfolios in period $t+1$ and adjust the returns by applying the risk factors of the Carhart (1997) four-factor model. Panel A of Table 3 report the results of the four-factor alphas for different geographical samples.

\footnotetext{
${ }^{6}$ These results are in line with empirical findings for domestic US funds as presented in Yan (2006) and Simutin (2014).
} 
[Insert Table 3 about here]

We find that in all geographical samples (pooled, US, EU, France, Luxembourg, and Germany) there is no significant relationship between cash and future risk-adjusted returns. In line with common intuition, the relationship between cash and future performance is negative in the EU, France, and Germany.

We then investigate the relationship between abnormal cash and future performance. As in Simutin (2014), we define a fund's abnormal cash as the residuals in a regression of cash on different fund characteristics. Specifically, in this paper, we compute abnormal cash for a given fund as the residuals of regression equation (1). As before, we then perform equal-weighted univariate portfolio sorts using abnormal cash in period $t$ and compute riskadjusted future fund performance in period $t+1$. Results are displayed in Panel B of Table 3 .

In contrast to the results we obtain when using raw cash, funds with high abnormal cash outperform their low abnormal cash peers in all geographical samples. The annualized spread between high and low abnormal cash funds is $0.98 \%$ in the whole sample, $1.06 \%$ for US funds, and $0.96 \%$ for EU funds with corresponding statistical significance at the $5 \%$ level. We also find annualized positive spreads of $1.22 \%, 0.88 \%$, and $0.96 \%$ for France, Luxembourg, and Germany. Hence, our results confirm the results of Simutin (2014) for a large sample of EU funds.

\section{Conclusion}

In this paper we analyze the determinants and performance implications of cash holdings for a large sample of actively-managed equity funds in the European Union. We find that cash holdings are strongly correlated to a fund's fee structure, past flows and flow volatility, and a fund's investment strategy. In line with the results of Simutin (2014), we find that high abnormal cash EU funds outperform low abnormal cash EU funds by $0.96 \%$ per annum. Our results support the notion that abnormal cash can be seen as a proxy for managerial ability enabling the fund manager to make superior stock selection decisions and also helps to retain costs triggered by unexpected outflows. 


\section{References}

Chernenko, S.; Sunderam, A. (2016). "Liquidity transformation in asset management. Evidence from the cash holdings of mutual funds." Unpublished Working Paper, Purdue University and Harvard Business School.

Chordia, T. (1996). "The structure of mutual fund charges". Journal of Financial Economics $41,3-39$.

Edelen, R. (1999). "Investor flows and the assessed performance of open-end mutual funds". Journal of Financial Economics 53, 439-466.

Hanouna, P.; Novak, J.; Riley, T.; Stahel, C. (2015). "Liquidity and flows of U.S. mutual funds.". Unpublished Working Paper, SEC Division of Economic and Risk Analysis.

Investment Company Factbook (2017). Investment Company Institute, Washington D.C, 57 th edition.

Simutin, M. (2014). "Cash holdings and mutual fund performance". Review of Finance 18, $1425-1464$.

Yan, X. (2006). "The determinants and implications of mutual fund cash holdings: Theory and evidence". Financial Management 35, 67-91. 
Figure 1: Aggregate Cash Holdings of US and EU funds over Time

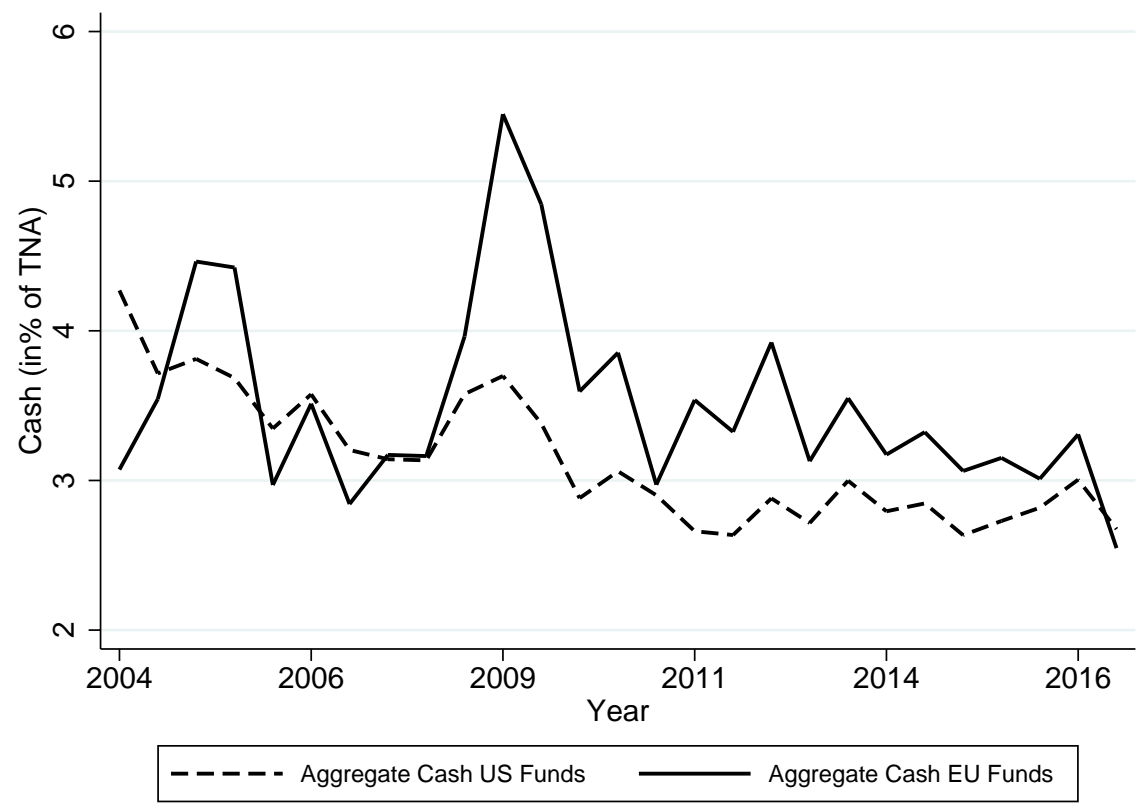

This figure displays the evolution of aggregate cash holdings over time, separately for US funds and EU funds. Aggregate cash is defined as the semi-annual, equal-weighted average of cash holdings as a percentage of TNA over all individual funds $i$ in period $t$ in our sample. The sample covers 2,166 actively-managed US equity funds and 1,464 actively-managed EU funds in the sample period from 2004 to 2017. 
Table 1: Summary Statistics

Panel A of this table presents the number of funds and number of observations for our sample differentiated by the funds' domiciles. Panel B of this table presents summary statistics for the main variables in the empirical analysis for all funds, US funds, and EU funds in our sample. The main variables include a fund's cash holdings (in \% of TNA), size (log of TNA), age (in years), expense ratio, six-months return (in \%), six-months flow (in \%), flow volatility (computed as the volatility of monthly net flows over the past 36 months), and its sensitivites with regard to the market return $\left(\beta_{M K T}\right)$, the size factor $\left(\beta_{S M B}\right)$, the value factor $\left(\beta_{H M L}\right)$, and the momentum factor $\left(\beta_{U M D}\right)$ of the Carhart (1997) four-factor model. To compute funds' sensitivites to different risk factors we apply the US Carhart (1997) four-factor model for US funds, and the European Carhart (1997) four-factor model for EU funds. Individual fund betas with regard to the market factor (MKT), the size factor (SMB), the value factor (HML), and the momentum factor (UMD) are estimated over a rolling horizon of 36 months. The last column computes the mean differences between the variables for the US and the EU with corresponding significance level. The sample covers 2,166 actively-managed US equity funds and 1,464 actively-managed EU funds in the sample period from 2004 to 2017. T-statistics are in parentheses and are computed using Newey and West (1987) standard errors with 4 monthly lags. ***, ${ }^{* *}$, and ${ }^{*}$ indicate significance at the one, five, and ten percent levels, respectively.

\section{Panel A: Sample}

\begin{tabular}{lcc}
\hline Country & Number of Funds & Number of Observations \\
\hline USA & 2,166 & 37,378 \\
Austria & 84 & 1,027 \\
Belgium & 57 & 549 \\
Denmark & 3 & 52 \\
Estonia & 1 & 12 \\
Finland & 81 & 1,201 \\
France & 410 & 4,720 \\
Germany & 188 & 3,236 \\
Greece & 2 & 21 \\
Ireland & 61 & 606 \\
Italy & 40 & 686 \\
Luxembourg & 469 & 6,127 \\
Netherlands & 35 & 376 \\
Portugal & 8 & 149 \\
Slovenia & 3 & 13 \\
Spain & 22 & 419 \\
\hline All & 3,630 & 56,572 \\
\hline
\end{tabular}

Panel B: Main Variables

\begin{tabular}{l|cccc|cccc|c}
\hline \multirow{2}{*}{ Variable } & \multicolumn{4}{|c}{ US Funds } & \multicolumn{3}{c}{ EU Funds } & \multicolumn{2}{c}{ Mean } \\
& Obs. & Mean & Median & Std Dev & Obs. & Mean & Median & Std Dev & Difference \\
\hline Cash (in \%) & 37,378 & 3.04 & 2.17 & 3.21 & 19,194 & 3.42 & 2.11 & 4.23 & $-0.38^{* * *}$ \\
Size (log of TNA) & 37,378 & 20.03 & 20.06 & 1.70 & 19,194 & 18.81 & 18.76 & 1.39 & $+1.22^{* * *}$ \\
Age (in years) & 37,378 & 15.96 & 13.33 & 12.17 & 19,194 & 14.02 & 12.24 & 9.14 & $+1.94^{* * *}$ \\
Expense Ratio (in \%) & 37,378 & 1.03 & 1.03 & 0.39 & 19,194 & 1.77 & 1.73 & 0.69 & $-0.74^{* * *}$ \\
Return 6-months (in \%) & 37,378 & 4.81 & 5.46 & 11.79 & 19,194 & 4.74 & 4.86 & 14.97 & +0.07 \\
Flow 6-months (in \%) & 37,378 & 2.02 & -1.26 & 13.87 & 19,194 & 1.44 & -1.15 & 12.61 & +0.58 \\
Flow Vola & 37,378 & 10.75 & 9.21 & 6.42 & 19,194 & 10.07 & 8.53 & 5.83 & $+0.68^{* * *}$ \\
$\beta_{M K T}$ & 37,378 & 0.99 & 1.02 & 0.25 & 19,194 & 1.02 & 1.14 & 0.49 & $-0.03^{*}$ \\
$\beta_{S M B}$ & 37,378 & 0.29 & 0.22 & 0.43 & 19,194 & 0.52 & 0.35 & 0.79 & $-0.23^{* * *}$ \\
$\beta_{H M L}$ & 37,378 & -0.01 & -0.01 & 0.30 & 19,194 & 0.23 & 0.08 & 0.55 & $-0.24^{* * *}$ \\
$\beta_{U M D}$ & 37,378 & 0.03 & 0.02 & 0.22 & 19,194 & 0.28 & 0.07 & 0.52 & $-0.25^{* * *}$ \\
\hline
\end{tabular}


Table 2: Determinants of Cash Holdings

This table presents the results of multivariate Fama-MacBeth (1973) regressions of a fund's future cash in period $t+1$ on a fund's size (log of TNA), age (in years), expense ratio, six-months return (in \%), six-months flow (in \%), flow volatility (computed as the volatility of monthly net flows over the past 36 months), and its sensitivites with regard to the market return $\left(\beta_{M K T}\right)$, the size factor $\left(\beta_{S M B}\right)$, the value factor $\left(\beta_{H M L}\right)$, and the momentum factor $\left(\beta_{U M D}\right)$ of the Carhart (1997) four-factor model. To compute funds' sensitivites to different risk factors we apply the US Carhart (1997) four-factor model for US funds, and the European Carhart (1997) four-factor model for EU funds. Individual fund betas with regard to the market factor (MKT), the size factor (SMB), the value factor (HML), and the momentum factor (UMD) are estimated over a rolling horizon of 36 months. The last column shows the sign of the predicted effect for each variable (for US funds and EU funds, respectively). The sample covers 2,166 actively-managed US equity funds and 1,464 actively-managed EU funds in the sample period from 2004 to 2017. T-statistics are in parentheses and are computed using Newey and West (1987) standard errors with 4 monthly lags. ${ }^{* * *},{ }^{* *}$, and ${ }^{*}$ indicate significance at the one, five, and ten percent levels, respectively.

\begin{tabular}{|c|c|c|c|c|c|c|c|}
\hline & $\begin{array}{c}\text { (1) } \\
\text { Cash } \\
\text { All Funds }\end{array}$ & $\begin{array}{c}(2) \\
\text { Cash } \\
\text { US Funds }\end{array}$ & $\begin{array}{c}(3) \\
\text { Cash } \\
\text { EU Funds }\end{array}$ & $\begin{array}{c}(4) \\
\text { Cash } \\
\text { France }\end{array}$ & $\begin{array}{c}(5) \\
\text { Cash } \\
\text { Luxembourg }\end{array}$ & $\begin{array}{c}(6) \\
\text { Cash } \\
\text { Germany }\end{array}$ & $\begin{array}{l}\text { Overall Effect } \\
\text { US Funds vs. } \\
\text { EU Funds }\end{array}$ \\
\hline Size & $\begin{array}{c}-0.0496 \\
(-1.60)\end{array}$ & $\begin{array}{c}0.0588^{*} \\
(1.83)\end{array}$ & $\begin{array}{c}-0.260^{* * *} \\
(-6.05)\end{array}$ & $\begin{array}{l}-0.134 \\
(-1.10)\end{array}$ & $\begin{array}{l}0.279 \\
(0.46)\end{array}$ & $\begin{array}{l}-0.166 \\
(-1.61)\end{array}$ & $+/-$ \\
\hline Age & $\begin{array}{c}0.00730^{* *} \\
\quad(2.67)\end{array}$ & $\begin{array}{c}0.0102^{* * *} \\
(4.00)\end{array}$ & $\begin{array}{c}-0.00948 \\
(-1.53)\end{array}$ & $\begin{array}{c}-0.0367 \\
(-1.25)\end{array}$ & $\begin{array}{l}-0.175 \\
(-1.44)\end{array}$ & $\begin{array}{c}-0.0009 \\
(-0.11)\end{array}$ & $+/-$ \\
\hline Expense Ratio & $\begin{array}{c}1.113^{* * *} \\
(10.13)\end{array}$ & $\begin{array}{c}1.443^{* * *} \\
(14.98)\end{array}$ & $\begin{array}{c}0.837^{* * *} \\
(7.01)\end{array}$ & $\begin{array}{c}0.843^{* * *} \\
(6.50)\end{array}$ & $\begin{array}{c}1.578^{*} \\
(1.72)\end{array}$ & $\begin{array}{c}0.902^{*} \\
(1.90)\end{array}$ & + \\
\hline Return 6-months & $\begin{array}{c}0.00999 \\
(0.60)\end{array}$ & $\begin{array}{c}0.0338^{* *} \\
(2.61)\end{array}$ & $\begin{array}{c}-0.0362 \\
(-0.84)\end{array}$ & $\begin{array}{r}0.0407 \\
(1.55)\end{array}$ & $\begin{array}{c}-0.0375 \\
(-0.20)\end{array}$ & $\begin{array}{l}-0.155 \\
(-1.37)\end{array}$ & $+/-$ \\
\hline Flow 6-months & $\begin{array}{c}0.0282^{* * *} \\
(7.21)\end{array}$ & $\begin{array}{c}0.0306^{* * *} \\
(7.76)\end{array}$ & $\begin{array}{c}0.0125^{* * *} \\
(3.55)\end{array}$ & $\begin{array}{c}0.0173^{*} \\
(1.73)\end{array}$ & $\begin{array}{c}0.0420^{*} \\
(1.86)\end{array}$ & $\begin{array}{c}0.0330 \\
(1.61)\end{array}$ & + \\
\hline Flow Vola & $\begin{array}{c}0.0300^{* *} \\
(2.55)\end{array}$ & $\begin{array}{c}0.0275^{* * *} \\
\quad(8.72)\end{array}$ & $\begin{array}{c}0.0527^{* * *} \\
(4.68)\end{array}$ & $\begin{array}{c}0.113^{* * *} \\
(3.35)\end{array}$ & $\begin{array}{c}0.0337 \\
(0.55)\end{array}$ & $\begin{array}{c}0.0456^{*} \\
(1.84)\end{array}$ & + \\
\hline$\beta_{M K T}$ & $\begin{array}{c}2.295^{* *} \\
(2.50)\end{array}$ & $\begin{array}{c}3.739^{* * *} \\
(2.83)\end{array}$ & $\begin{array}{c}2.249^{* *} \\
(2.37)\end{array}$ & $\begin{array}{c}1.141^{* *} \\
(2.19)\end{array}$ & $\begin{array}{c}3.498^{* *} \\
(2.56)\end{array}$ & $\begin{array}{l}2.550 \\
(1.13)\end{array}$ & + \\
\hline$\beta_{S M B}$ & $\begin{array}{l}0.202^{*} \\
(1.85)\end{array}$ & $\begin{array}{c}0.363^{* *} \\
(2.74)\end{array}$ & $\begin{array}{c}0.127^{* *} \\
(1.79)\end{array}$ & $\begin{array}{l}1.086^{*} \\
(1.96)\end{array}$ & $\begin{array}{c}0.0127 \\
(0.01)\end{array}$ & $\begin{array}{l}0.645 \\
(0.60)\end{array}$ & + \\
\hline$\beta_{H M L}$ & $\begin{array}{c}0.060 \\
(1.17)\end{array}$ & $\begin{array}{l}-0.019 \\
(-0.51)\end{array}$ & $\begin{array}{l}0.102 \\
(0.23)\end{array}$ & $\begin{array}{c}2.348^{* * *} \\
(2.97)\end{array}$ & $\begin{array}{l}-0.298 \\
(-0.28)\end{array}$ & $\begin{array}{l}1.263 \\
(0.58)\end{array}$ & $-/+$ \\
\hline$\beta_{U M D}$ & $\begin{array}{c}0.00571 \\
(0.02)\end{array}$ & $\begin{array}{c}-0.439^{*} \\
(-2.01)\end{array}$ & $\begin{array}{c}0.966 \\
(1.47)\end{array}$ & $\begin{array}{c}-1.923^{* * *} \\
(-3.22)\end{array}$ & $\begin{array}{l}1.762 \\
(1.17)\end{array}$ & $\begin{array}{l}0.480 \\
(0.29)\end{array}$ & $-/+$ \\
\hline Constant & $\begin{array}{c}5.469^{* * *} \\
(6.14)\end{array}$ & $\begin{array}{c}3.770^{* * *} \\
(4.14)\end{array}$ & $\begin{array}{c}11.36^{* * *} \\
(7.86)\end{array}$ & $\begin{array}{c}4.804^{* *} \\
(2.16)\end{array}$ & $\begin{array}{l}0.788 \\
(0.06)\end{array}$ & $\begin{array}{c}13.60^{* * *} \\
(3.13)\end{array}$ & \\
\hline$N$ & 53476 & 35344 & 18321 & 4545 & 5809 & 3117 & \\
\hline$R^{2}$ & 0.079 & 0.119 & 0.105 & 0.167 & 0.195 & 0.158 & \\
\hline
\end{tabular}


Table 3: Univariate Portfolio Sorts: Performance Implications

Panel A of this table reports results from univariate portfolio sorts based on a fund's cash in period $t$. In each period, we rank funds into quintiles (1-5) and form equal-weighted portfolios based on this measure. For each quintile portfolio, we compute the average Carhart (1997) four-factor alpha in period $t+1$. We apply the US Carhart (1997) four-factor model for US funds, and the European Carhart (1997) four-factor model for EU funds. The row labeled "High - Low" reports the difference between the alphas of portfolio 5 and portfolio 1, with corresponding statistical significance levels. Panel B of this table reports results from univariate portfolio sorts based on a fund's abnormal cash in period $t$. In each period, we rank funds into quintiles (1-5) and form equal-weighted portfolios based on this measure. For each quintile portfolio, we compute the average Carhart (1997) four-factor alpha in period $t+1$. We apply the US Carhart (1997) four-factor model for US funds, and the European Carhart (1997) four-factor model for EU funds. The row labeled "High - Low" reports the difference between the alphas of portfolio 5 and portfolio 1, with corresponding statistical significance levels. The sample covers 2,166 actively-managed US equity funds and 1,464 actively-managed EU funds in the sample period from 2004 to 2017. T-statistics are in parentheses and are computed using Newey and West (1987) standard errors with 4 monthly lags. ${ }^{* * *},{ }^{* *}$, and ${ }^{*}$ indicate significance at the one, five, and ten percent levels, respectively.

Panel A: Cash and Carhart (1997) alphas

\begin{tabular}{c|cccccc}
\hline Portfolio & All Funds & US Funds & EU Funds & France & Luxembourg & Germany \\
\hline 1 Low Cash & $-0.83 \%$ & $-0.64 \%$ & $-0.90 \%$ & $-1.09 \%$ & $-0.37 \%$ & $-0.30 \%$ \\
2 & $-0.52 \%$ & $-0.33 \%$ & $-0.81 \%$ & $-1.51 \%$ & $-0.74 \%$ & $-0.69 \%$ \\
3 & $-0.61 \%$ & $-0.54 \%$ & $-0.62 \%$ & $-1.11 \%$ & $-0.17 \%$ & $-0.97 \%$ \\
4 & $-0.54 \%$ & $-0.44 \%$ & $-0.85 \%$ & $-1.21 \%$ & $-0.34 \%$ & $-1.10 \%$ \\
5 High Cash & $-0.68 \%$ & $-0.35 \%$ & $-0.96 \%$ & $-1.07 \%$ & $-0.24 \%$ & $-0.67 \%$ \\
\hline High - Low & $0.15 \%$ & $0.29 \%$ & $-0.06 \%$ & $-0.02 \%$ & $0.13 \%$ & $-0.37 \%$ \\
& $(1.04)$ & $(1.21)$ & $(-0.22)$ & $(-0.14)$ & $(0.69)$ & $(-0.94)$ \\
\hline
\end{tabular}

Panel B: Abnormal Cash and Carhart (1997) alphas

\begin{tabular}{c|cccccc}
\hline Portfolio & All Funds & US Funds & EU Funds & France & Luxembourg & Germany \\
\hline 1 Low Abnormal Cash & $-1.08 \%$ & $-0.73 \%$ & $-1.18 \%$ & $-1.51 \%$ & $-0.24 \%$ & $-0.94 \%$ \\
2 & $-0.54 \%$ & $-0.48 \%$ & $-0.82 \%$ & $-1.26 \%$ & $-0.48 \%$ & $-1.06 \%$ \\
3 & $-0.42 \%$ & $-0.51 \%$ & $-0.78 \%$ & $-1.19 \%$ & $-0.46 \%$ & $-0.50 \%$ \\
4 & $-0.55 \%$ & $-0.35 \%$ & $-0.85 \%$ & $-1.9 \%$ & $-0.30 \%$ & $-0.51 \%$ \\
5 High Abnormal Cash & $-0.59 \%$ & $-0.20 \%$ & $-0.70 \%$ & $-0.90 \%$ & $+0.20 \%$ & $-0.46 \%$ \\
\hline High - Low & $0.49 \%^{* *}$ & $0.53 \%^{* *}$ & $0.48 \%^{* *}$ & $0.61 \%^{*}$ & $0.44 \%$ & $0.48 \%^{*}$ \\
& $(2.16)$ & $(2.07)$ & $(2.05)$ & $(1.70)$ & $(1.14)$ & $(1.90)$ \\
\hline
\end{tabular}

